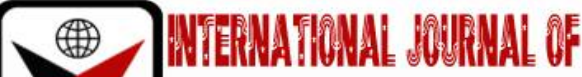

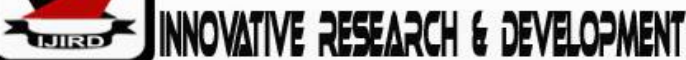

ISSN 2278-0211 (Online)

\section{Women Folk in Sokoto Caliphate: A Historical Overview on their Roles and Contributions in the 19th Century Islamic Movement in Hausaland}

\author{
Nabilah Lawal Bako \\ Lecturer, Department of History, Sokoto State University, Sokoto, Nigeria
}

\begin{abstract}
:
In most parts of the world, females are regarded and considered as inferior to their male counterparts in the development of a society. Certainly, the role of women in any society is very enormous. They are the mothers and thus, the backbone of any society. Yet, the most striking thing is that very little attention has actually been accorded to their contributions. In West Africa, research studies have been conducted on women in different societies within the sub region. However, the findings are not adequate and properly documented. Hence, serious attention needs to be given to the role of women in both old and contemporary societies, more especially in the Islamic West African Sub-region which has witnessed progressive societies in the $17^{\text {th }}$ and $18^{\text {th }}$ centuries. Among these societies include Sokoto Caliphate; where women left an indelible mark in the success of the Jihad movement. They contributed to the development of their various societies intellectually, morally, and economically. This necessitates the need to outline the contributions of women to the progress and prosperity of this great Caliphate.
\end{abstract}

Keywords: Islamic Movement and Sokoto Caliphate

\section{Introduction}

The ideological basis of the $19^{\text {th }}$ century Islamic movements was to purify Islam tauhid, pristine sunnah and eradicate injustice. Hence, these gave the basis on the establishment of a true Islamic society based on social justice and governance in order to undermine tribe and tribalistic loyalties and replacing them with royalties to the brotherhood. ${ }^{1}$ Similarly, the movement was indeed an intellectual one that changed the course in Hausa land and even beyond. Shaikh Uthman Bn Fodio, his brother Abdullahi and son Muhammad Bello under took series of measures in revolutionizing Hausa land. The activities of these prime movers inspired the outbreak of similar Jihads elsewhere like the Jihad of Alhaji Umar Labbo in Masina and that of Umar Al Futi in Senegambia and parts of Mali. ${ }^{2}$ But that of the triumvirate was perhaps the most spectacular with far reaching changes.

Moreover, the most outstanding legacy and contribution left by the Jihadist was the literary works written by them, which remain relevant even in the contemporary West Africa. Part of the area of their achievement was the liberation struggle of women folk from the domination of men folk. In fact, the contributions of Nana Asma'u in the field of education remain a significant issue in West African History. It is not an exaggeration to say that the history of the jihad will never be complete without looking at the crucial role of women towards the success of the Jihad and establishment of Sokoto Caliphate.

\section{Conceptual Clarifications}

\subsection{The Key Concepts to be Conceptualized Here are Islamic Movement and Sokoto Caliphate}

\subsubsection{Islamic Movement}

Islamic Movement is an inspirational movement that is deeply rooted in Islam. The movement is aimed at renewing, reconstructing, and reviving Islam, and its basic tenets. ${ }^{3}$ The $19^{\text {th }}$ century Islamic movement in West Africa witnessed a series of revolutionary activities that consequently reached a terminal stage of waging a Jihad Holy War. Jihad is the Arabic word, for what can be variously translated as struggle, effort, to strive, to exert or to fight, depending on the

\footnotetext{
1. M.U.,Bunza (2005). The North Africa Factor in Tajdeed Tradition in Hausa land, Northern Nigeria, in the Journal of North African Student, Taylor and Francis group, Oxford, Vol. 10, No. $3-4$.

2. M. Last, (1997).The Sokoto Caliphate, Longman, London. See also: D. Bennett, et al, A History of World Societies, Vol. 2; 1950 , Macmillan, P.755.

3. http://www.Ask.com/Wiki/IslamicJihad, Retrieved on 24/09/11 and http://www.googlesearch.com/wiki/Islamic movement in West Africa, Retrieved on $02 / 02 / 16$.
} 
context. ${ }^{4}$ It is seen as a military struggle on behalf of Islam. But mostly refers to an internal, individual, spiritual, struggle toward self-improvement, moral cleansing and intellectual effort.5Jihad can be described as the outcome of the theological reasoning and the discussion of Muslim intellectuals and jurist, who regard Jihad as a collective duty incumbent upon the Muslim community at large. ${ }^{6}$

Sokoto Caliphate was an independent Islamic Caliphate in West Africa, Established in 1809, by Usmanu Dan Fodiyo. Developed in the context of multiple, independent Hausa Kingdoms, at its height the Caliphate linked over 30 different emirates and over 10 million people in the most powerful state in its region, and was one of the most significant empires in Africa in the nineteenth century. ${ }^{7}$ The Caliphate was a loose confederation of emirates that recognized the suzerainty of the "Commander of the Faithful". Usmanu Danfodiyo's Jihad provided the inspiration for series of related Jihads in other parts of the Savannah and Sahel, far beyond Nigeria's borders that led to the foundation of Islamic States in Senegal, Mali, Ivory Coast, Chad, Central African Republic and Sudan. ${ }^{8}$ The Caliphate was attacked and defeated by the British West African Frontier Force in 1903 and put the area under the northern Nigerian protectorate.

\section{Status of Women in the Pre-Jihad Society}

Women in Islamic States enjoyed sound status based entirely on the commandments of Allah and his Prophet. However, with the passage of time, women began to witness changes in their status probably due to the following;

- Islam as a religion was not firmly established among some of the communities.9

- The Ulama's (Islamic Teachers) failed vigorously to pursue the rights of women in their communities. ${ }^{10}$

- And the failure of Muslim parents and husbands to uphold such rights in respect of woman. ${ }^{11}$

Therefore, it is not surprising to find in this situation the abuse of womanhood in all aspects of life. For instance, in the economic aspect, the inequality fought by Islam in redistribution of wealth in favor of women resurfaced. ${ }^{12}$ The rights of women to inherit in all circumstances were tampered with. Even the dowry that women were supposed to be given by their husbands on marriages found its way into the pockets of some elders in the family and Ulama's. ${ }^{13}$ Likewise, in the field of education, the scholars, parents, and husbands abandoned women in total ignorance. They were denied the knowledge of individual, personal obligations governing the conduct of their faith, worship and business transactions. ${ }^{14}$ Rather, scholars taught their students outside while they left their wives and daughters in ignorance. They prevented them from going in search of knowledge even though they allowed them to attend social functions where women mixed with men and even dances in public. It is in line with these that Kani asserts that:

In order to uncover the arrogance and ignorance of this group, the Jihad leaders went to the extent of quoting a practical example that this group of people see their women illegally attending marriage ceremonies, singing and dancing intermixing with men.......but when they see them going out in pursuit of learning they say this is repressive. ${ }^{15}$

Similarly, in marital life, women were treated like slaves with the help of venal scholars; subservience to husbands was emphasized at the expense of obedience to God. Men used the opportunity to over burden women with domestic chores, cooking, and the like. Women were also used on farmlands for manual labor which uplifted the social status of men. ${ }^{16}$ However, the Islamic reformers were outraged with the status of women in the society, because it reduced women to amusement items on display for the enjoyment of men. ${ }^{17}$ Consequently the desire for change in the society became a paramount issue to be dealt with by the scholars.

\section{The Emancipation of Women in Hausaland}

The triumvirates played a prominent role in the liberation of women from the bondage and ignorance as stated by Kaura. ${ }^{18}$ He further illustrated how the Jihad leaders transformed the status of womanhood into a sound and free life style that is strictly on the teachings of Islam and commandment of Allah and the Prophet. ${ }^{19}$ They preached on the dangers of unlicensed freedom of movement of women which spread corruption in womanhood. Emphasis was given to the fact that;

\footnotetext{
4. http://www.Ask.com/Wiki/IslamicJihad, Retrieved on 24/09/11 and http://www.googlesearch.com/wiki/Islamic movement in West Africa, Retrieved on $02 / 02 / 16$

5. http://www.Ask.com/Wiki/IslamicJihad, Retrieved on 24/09/11 and http://www.googlesearch.com/wiki/Islamic movement in West Africa, Retrieved on $02 / 02 / 16$.

6. T. AAhaolu et.al,(1975).A History of West Africa, A. D. One Thousand to present day, Ibadan, P.55.

7. H. Chapin, (1991), eds. "Usman Danfodio and the Sokoto Caliphate" Nigeria: A Country Study, Washington, GPO for the Library of Congress. Retrieved 02/09/15.

8. H. Chapin, (1991). eds. "Usman Danfodio and the Sokoto Caliphate" Nigeria: A Country Study...P.12.

9. A. M, Kani and K.A,Gandi, (1990), eds, State and Society in Sokoto Caliphate, Usmanu Danfodiyo University Press, Sokoto, P. 74.

10 A. M, Kani and K.A, Gandi, (1990), eds, State and Society in Sokoto Caliphate... P. 74.

11.A. M, Kani and K.A, Gandi, (1990), eds, State and Society in Sokoto Caliphate... P. 75-6.

12. J. M. Kaura, (1990), "Emancipation of Women in the Sokoto Caliphate" in A. M. Kani and K.A. Gandi, (eds) State and Society in Sokoto Caliphate. Usmanu Danfodiyo University Press, Sokoto, 1990, P.79.

13. J. M. Kaura, (1990), "Emancipation of Women in the Sokoto Caliphate" in A. M. Kani and K.A. Gandi, (eds) State and Society in Sokoto Caliphate....... P.79-80.

14.J. M. Kaura, (1990), "Emancipation of Women in the Sokoto Caliphate" in A. M. Kani and K.A. Gandi, (eds) State and Society in Sokoto Caliphate...... P.80-81.

15. A.M. Kani and K. A. Gandi, (1990), eds, State and Society in Sokoto Caliphate, P.75.

16. J. M. Kaura, (1990), "Emancipation of Women in the Sokoto Caliphate" .......P.80

17. D. Robinson,(no date), "Revolutions in the Western Sudan" Levtzion\&Povwels (eds) The History of Islam in Africa,Athens, Ohio University Press, P.22.

18. J. M. Kaura, (1990), "Emancipation of Women in the Sokoto Caliphate”......P.81.

19.J. M. Kaura, (1990), "Emancipation of Women in the Sokoto Caliphate"........P81.
} 
women should be allowed to go out when the need arises. Such basic needs both religious and mudanes ones, as enumerated by Shaikh Uthman in his book Irshdullkhwan Ila Akham Khurujul Niswan. He pointed out that: It is mandatory that they should be taught the Sunnah of Prophet in respect of the way a woman shall go out. That a woman shall go out in her uglier and thick dress...20 This is addition to restraining from talking to or looking at men. The aim was to stop women being attractive to men. ${ }^{21}$ They also fought against fornication and warned fornicators to give up this shameful act. This could be evident in their local vernacular poetry works such as Tabban hakika composed by Shaikh himself22and Bulaliya which Abdullahi composed at the court of king Bawa of Gobir were Abdullahi postulate that: "People you should fear, faithful men and women you should give up fornication".23Thus, the spread of poetry in local vernacular was more or less an effort towards saving the dignity of womanhood. Kaura, further states the efforts made by the reformers to support women and ensure that their rights were not trampled on, especially on rules governing inheritance, dowry, and above all education. ${ }^{24}$ In Irshad al Ikhwan Ila Ahkamkhuruj al Niswan, Shaikh Uthman laments that it is obligatory on a woman to acquire a full knowledge of her religious obligations such as Prayer, Fasting, Zakkat, Hajj, as well as the more mudane matters such as trade and transactions. ${ }^{25}$ In Nural-Albab, he mention that scholars who opposed women's education were merely hypocrites. ${ }^{26}$ However, the impact of educational revolution on women could be viewed and assessed from the contributions made by the Jihad leaders in Hausa land and other parts of West Africa.

\section{The Role of Women in the Growth and Development of Sokoto Caliphate}

One of the impacts of the $19^{\text {th }}$ century Islamic movement was the successful creation and establishment of an Islamic empire popularly known as the Sokoto Caliphate. Women, being the backbone of every community played eminent role in this regard. They did not take arms and fought in the battle fields like their male counterparts when the need arose, but rather, assisted in various capacities which the paper intends to highlight. However, their contributions could be categorized in two broad perspectives, i.e. the formative and consolidative periods. In the formative period, women folk under the auspices of the Shaikh's wives (Hauwa'u, Aisha etc) and daughters prominent among of whom were: Nana khadija, Fadimatu, Maryam and Nana Asma'u served as vanguards of Education. They played a great role in disseminating knowledge to their female counterparts, children and the community at large. ${ }^{27}$

The greatest contribution of Nana Asma'u which signifies her political and sophistication is the Yan taru movement. Yan taru means associates. It is the backbone of her teaching philosophy and the soul of her reform strategy. Under this initiative, she reached out to rural societies with elderly women and girls as her student coming from various ethnic groups. ${ }^{28}$ She also established a cadre of literate, itinerant women teachers (Jajis) who disseminated her instructive poetic works among the masses and secluded women in the privacy of their homes. ${ }^{29}$ Asma'u's main focus was to educate women in order to equip them to bring up the next generation of children within the desired ideological framework.

Furthermore, the women's active and labor-intensive preparation of material goods necessary to both battle and the itinerant life that resulted from warfare allowed for the survival of these Muslims. ${ }^{30}$ Their industriousness and dedication produced spun thread to make into battle garments, crafted containers for the reservation of food and water. All of these were carried out continuously over many years of living in temporary settlement and in a harsh environment of few resources. They supply food and beverages and also shouldered the responsibility for nursing the wounded men in the battles and helping to transport them as they fled in the face of enemy's attack. ${ }^{31}$

Similarly, during the consolidative period, the women contributed greatly in the preservation of the history of the Jihad and the Caliphate. They undertook the task of translating the works of the Jihad leaders especially into Hausa from Arabic and Fulfulde languages respectively. ${ }^{32}$ Thus, this will ensure a wide audience for the writings of one of the most influential men of history. In the field of preaching, women gave their own contributions through their widely spread of poems and literal works both in Arabic and Local languages. They also composed historical poems on almost all the period of the Jihad. Examples of poems written by Nana Asma'u are 'wakargewaye' which was about the travels of her father and his community during the early years of the Jihad, others include Sufi women, Elegy for my sister Fatima, Elegy for Bello,

20. S.U. Danfodiyo, (no date), Irshad Al IkhwanIlaAhkamKhuruj Al-Niswan. Manuscript, P. 4.

21. S.U. Danfodiyo, (no date), Irshad Al IkhwanIlaAhkamKhuruj Al-Niswan. Manuscript, P. 4.

22. S.U. Danfodiyo, (no date), Irshad Al IkhwanIlaAhkamKhuruj Al-Niswan. Manuscript, P. 5. See also, H. Bobboyi and A. M. Yakubu,(2006), (eds), Sokoto State Caliphate, History and Legacies, 1804 -2004, Vol. II, Baraka Press and Publishers, Kaduna.P.45.

${ }^{23}$.H. Bobboyi and A. M. Yakubu,(2006), (eds), Sokoto State Caliphate, History and Legacies, 1804 -2004, Vol. II,

Baraka Press and Publishers, Kaduna. P.45.

24 .J. M. Kaura, (1990), "Emancipation of Women in the Sokoto Caliphate".......P.84.

25. S.U. Danfodiyo, (no date), Irshad Al IkhwanIlaAhkamKhuruj Al-Niswan. Manuscript, P.6.

${ }^{26 . S . U . D a n f o d i y o,(n o ~ d a t e), ~ N u r ' a l-A l b a b, ~ M a n u s c r i p t, ~ P .4 . ~ S e e ~ a l s o ~ J . ~ B o y d, ~ " T h e ~ R o l e ~ o f ~ E d u c a t e d ~ W o m e n ~ i n ~ S o k o t o ~ C a l i p h a t e: ~ N a n a ~ A s m a ' u, ~ 1793 ~-~ 1865 " ~}$ in H. Bobboyi and A. M. Yakubu,(2006), (eds.),The Sokoto Caliphate, History and Legacies, 1804 - 2004, Vol. II, Baraka Press and Publishers, Kaduna. P.124.

${ }^{27}$.S.U .Danfodiyo, (no date), Nur'al-Albab, Manuscript, P.4. See also J. Boyd,(2006), “The Role of Educated Women in Sokoto Caliphate: Nana Asma'u, 1793 - 1865" in H. Bobboyi and A. M. Yakubu,(2006), (eds.), The Sokoto

Caliphate, History and Legacies, 1804 - 2004, Vol. II, Baraka Press and Publishers, Kaduna. P.124.

28. B. B. Mack, and J. Boyd, (2000),One Woman's Jihad: Nana Asma'u, Scholar and Scribe, Indiana University Press, U.S.A. P.22.

29. B. B. Mack, and J. Boyd,(2000), One Woman's Jihad: Nana Asma'u, Scholar and Scribe, Indiana University Press, U.S.A, P.22.

30.S. U. Lawal,(1981), “Women and 1804 Jihad”, Seminar Paper, March, P.6.

31.S. U. Lawal,(1981), "Women and 1804 Jihad", Seminar Paper, March, P.7.

32. J. Boyd and B. B. Mack,(1999),TheCollected Works of Nana Asma'u, Daughter of Usmanu Danfodiyo, 1795 -

1864, Sam Bookman Publishers, Ibadan, P.9. Also in J. Boyd,(2006), "The Role of Educated Women in Sokoto Caliphate", ....P.125. 
victory at gawakukeetc. ${ }^{33}$ Khadija, the eldest daughter of Shaikh made immense contributions in the field of science of Muslim Jurisprudence (Fikh) and Arabic grammar. She also wrote on Mahdi, Mallam Tafa among others. ${ }^{34}$ Fatima composed poems on elderly people, that they should not seek admonishment from preachers but rather look at the hair of their head, eyes, sense of hearing and mouth for admonishment. ${ }^{35}$

Meanwhile, in the field of administration of the Caliphate, women contributed their own quota. The jihad leaders involved women in running the Caliphate with the power to advice and make their views known. ${ }^{36} \mathrm{An}$ example was when Nana Asma'u was reported to have intervened when Khalilu was appointed as the Vizer and Muhammad Laima refused to acknowledge the famous appointment. She consoled Muhammad Laima and succeeded in getting him appointed as Dangaladima to Khalilu. Thus, assuring him of the Vizerate after Khalilu ${ }^{37}$ In the same vein, Maryam (sister of Nana) happen to be consulted a political issues by the Emir of Kano, Uthman Ibn Dabo.38 She also suggested the appointment of Muhammad Bello as the Emir of Kano when controversy started after the death of the former Emir Abdullahi. This buttressed the assertion that they were politically consulted even on sensitive issues in the Caliphate. ${ }^{39}$ The political decisions and the advice given by women showed that they were politically recognized and obeyed. Their views were not only respected but were also regarded as arbiters. Thus, it is clear that Islam allows women to participate in politics that suited their natural dispositions, which does not necessarily give them any political recognition as elected officials with offices to run governments.

The success of women's contribution to the economic development of Sokoto caliphate was as a result of a concrete attempt over a long period to mobilize women to actively participate in the caliphates economy. ${ }^{40}$ Nothing perhaps motivated and encouraged women more to realize their role and give their own contribution for the betterment of the then society than the call of Muhammadu Bello in his book An-Nasiha al wadia. Muhammad Bello appealed to Muslim women to give their help and support, so as to defeat the potential evil and destroy the stem of societal decay. ${ }^{41}$ In this regard, women doubled their efforts and ventured into different economic potentialities for the growth and development of the caliphate. They were originally on the home front; performing their reproductive and nurturing functions, house hold chores, taking care of the sick and elderly in the family etc. ${ }^{42}$

Women were also found on farm and fields, they engaged in agricultural practices all year round such as planting, harvesting, beating, winnowing, threshing, packaging and storing. It was the responsibility of women to process grains which must be done prior to sale or consumption. ${ }^{43}$ Women also engaged in rearing of domesticated animals such as, cow, sheep, goat, guinea fowl, chicken etc. Women used to feed the animals, clean their sheds and milk cows and goats at home. They store and ferment the milk and separate manshanu (butter) from the milk, which were used in cooking. ${ }^{44}$ Another area where women engaged themselves and participated fully include;

Food and catering industry, manufacturing of soap and cream, production of local cigarettes (tabagari), hair dressing, weaving of mats, local fans, cover lids etc. Pottery, spinning and weaving of cloths, tie and dye, sewing and decorating leather works, beads and accessories production. Women served as grain measurers/ sellers, commissioned agents, water vendors, aphrodisiac vendors, traditional midwives and barbers, among others. ${ }^{45}$

\section{Conclusion}

Islam as a way of life sanctifies the lives of women like any other human being. Perhaps the $19^{\text {th }}$ century Islamic movements in Hausa land unveiled the true potentialities and great qualities of womanhood. They played an immense role towards the successful growth and development of the caliphate from the beginning to the climax. They portrayed their ideal values and selfless service towards building a distinct Islamic state in the whole of West Africa. Their efforts and contributions were important in understanding the contemporary situations and chaos womanhood are exposed to. In the contemporary world, women are secluded and were given minimum rights to participate in the society. Today, $70 \%$ of women in city of Sokoto are not secluded, but have little rights and privileges to participate in the development of the state. They are many educated and qualified women, but the problem is that they are not recognized and are over powered by their male counterpart in all ramifications. The government does little to assist and encourage women and youth to be self-reliant. Even those that are into petty trading, small and medium scale enterprises are on the verge of collapse, due to poor market as a result of inflation. Hence, the government needs to buckle up and encourage the participation of women

33. J. Boyd, (2006), “The Role of Educated Women in Sokoto....”, P.126-7.

34.M. J. Yusha'u ,(2004), Nana Asma’u Tradition: “An Intellectual Movement and a Symbol of Women Rights in Islam during the $19^{\text {th }}$ Century Danfodiyo's Islamic Reform”. A Paper Presented at the Conference on Sokoto Jihad Organized by the Centre for Hausa Cultural Studies Kano, at Murtala Muhammad Library, 7-8 th $^{\text {th }}$ e.

35.M. J. Yusha'u, (2004), Nana Asma'u Tradition: “An Intellectual Movement and a Symbol of Women Rights in Islam during the $19^{\text {th }}$ Century Danfodiyo's Islamic Reform". A Paper Presented at the Conference........P.5.

${ }^{36}$. M. J. Yusha'u, (2004), Nana Asma'u Tradition: “An Intellectual Movement and a Symbol of Women Rights in

Islam during the 19th Century Danfodiyo's Islamic Reform”. A Paper Presented at the Conference .......P.6.

${ }^{37}$.J. Boyd ,(2006), "The Role of Educated Women,........ "P.126.

38.J. Boyd, (2006), "The Role of Educated Women,........ "P.127-8.

${ }^{39}$.S. U. Lawal, (1981)," Women and 1804 Jihad"......P.8.

${ }^{40}$.H.U. Malami, (1998).Economic Principles and Practices of the Sokoto Caliphate, Institute of Islamic Sciences Sokoto, P.81.

41.M.Bello, (no date), An-Nasiha Al Wadi'a. Manuscript. P.3-4.

42.H.U. Malami, (1998). Economic Principles and Practices of the Sokoto Caliphate..... P.82-3.

${ }^{43}$.H.U. Malami,(2006). The Role of Women in the Economic Development of Sokoto Caliphate. Center for Islamic Studies, Usmanu Danfodiyo University, Sokoto.P.38

${ }^{44}$.H.U. Malami,(2006). The Role of Women in the Economic Development of Sokoto Caliphate P.39-41.

45.N.L Bako, (in view). “Women Entrepreneurship in Sokoto City, 1809-1903'. An article to be published in a book title: A History of Women in Northern Nigeria, to be edited by A.B, Bawa and Y.Abubakar, Department of History, Usmanu Danfodiyo University, Sokoto. 
in the economic, social and political development of the state. If the $19^{\text {th }}$ century jihad leaders can make it, why can't we imbibe with their teachings so as to have a better $21^{\text {st }}$ century city and state? On the whole, a woman should be given every opportunity in the society to exercise her rights and duties. She is a mother, a guardian and an eye for the community as such deserves to be recognized.

\section{References}

i. Bako, N.L., (in view). "Women Entrepreneurship in Sokoto City, 1809-1903'. An article to be publish in a book title: A History of Women in Northern Nigeria, to be edited by A.B, Bawa and Y. Abubakar, Department of History, Usmanu Danfodiyo University, Sokoto.

ii. Bello M, (no date), An-Nasiha Al Wadi'a. Manuscript.

iii. Bennett, D, et al, A History of World Societies, Vol II: 1450, Macmillan, 1972.

iv. Buhari B. K., Female Education in Sokoto Province, 1935 - 1960, Ph.D. Thesis, 2002.

v. Bunza M.U., "The North African Factor in Tajdeed Tradition in Hausaland", Northern Nigeria, in the Journal of North African Student, Taylor and Francis Group, Oxford, Vol.10, No.3 - 4, 2005.

vi. Danfodiyo, S.U, (no date), Irshad Al Ikhwan Ila AhkamKhuruj Al-Niswan. Manuscript.

vii. Danfodiyo, S.U, (no date), Nur'al-Albab, Manuscript.

viii. David R., "Revolutions in the Western Sudan" in Levtzion \& Pouwels (eds.) The History of Islam in Africa, Athens, ohio University Press.

ix. Helen C., (eds.), “Usmanu Danfodio and the Sokoto Caliphate” Nigeria: A Country Study, Washington, 1991, GPO for the Library of Congress. Retrieved 02/09/15.

x. http//:www.googlesearch/19thcenturyIslamicRevolution...

xi. http://www.Ask.Wiki/Islamic Jihad Retrieved on 24/09/11.

xii. Ibrahim S., A Revolution in History: The Jihad of Usmanu Danfodiyo, Mansell Publishing Limited, London and New York, 1987.

xiii. Jean B. and Mack, B. B., The Collected Works of Nana Asma'u, Daughter of Usmanu Danfodiyo,1793 - 1864, Sam Bookman Publishers, Ibadan, 1999.

xiv. Jean B., "The Role of Educated Women in Sokoto Caliphate: Nana Asma'u, 1793 - 1865" in Bobboyi H. and Yakubu A. M., (eds.), The Sokoto Caliphate, History and Legacies, 1804 - 2004, Vol. II, Baraka Press and Publishers, Kaduna, 2006.

xv. Kani A. M. and Gandi K. A., (eds.), State and Society in Sokoto Caliphate, Usmanu Danfodiyo University Sokoto Printing Press, Sokoto, 1990.

xvi. Kaura, J.M., "Emancipation of Women in Sokoto Caliphate", in Kani, A. M. and Gandi K.A. (eds.), State and Society in the Sokoto Caliphate, Usmanu Danfodiyo University, Sokoto, Nigeria, 1990.

xvii. Lawal, S.U., "Women and 1804 Jihad", Seminar Paper, March, 1981.

xviii. Mack, B. B. and Boyd, J., One Woman's Jihad; Nana Asmau'u Scholar and Scribe, Indiana University Press, U.S.A, 2000.

xix. Malami, H. U., Economic Principles and Practices of the Sokoto Caliphate, Institute of Islamic Sciences Sokoto, Sokoto, 1998.

xx. Malami, H.U.,The Role of Women in the Economic Development of Sokoto Caliphate. Center forIslamic Studies, Usmanu Danfodiyo University, Sokoto 2006.

xxi. Muhammad J. Y., Nana Asma'u Tradition: "An Intellectual Movement and A Symbol of Women Rights in Islam During the 19th Century Danfodiyo's Islamic Reform". A paper presented at the Conference on Sokoto Jihad organized by the Centre for Hausa Cultural Studies Kano, at Murtala Muhammad Library, 7 - 8 June, 2004.

xxii. Murray L., The Sokoto Caliphate, Longman, London, 1997.

xxiii. Tony Ade Ashaolu, et.al, A History of West African, A.D. One Thousand to Present Day, Ibadan, 1975. 